\title{
Properties of white birch (Betula papyrifera) outer bark particleboards with reinforcement of coarse wood particles in the core layer
}

\author{
Roger PEDIEU ${ }^{1}$, Bernard RIEDL ${ }^{1 *}$, André PICHETTE ${ }^{2}$ \\ ${ }^{1}$ Centre de recherche sur le bois (CRB), Pavillon Kruger, Université Laval, G1V0A6 Québec, Canada \\ ${ }^{2}$ Département des sciences fondamentales, Université Québec à Chicoutimi, Ville la-Baie, G7H2B1 Québec, Canada
}

(Received 5 February 2008; accepted 6 June 2008)

Keywords:

alkali treatment /

mixed particleboards /

outer bark of white birch /

mechanical properties /

physical properties

\begin{abstract}
- This study proposes substituting traditional raw materials in the surface layers of wood particleboards with the water resistant white birch (Betula papyrifera) outer bark particles, which can help improve the dimensional stability of manufactured mixed particleboards, thereby alleviating shortages of raw material in a cost-efficient manner.

- Mixed particleboards were fabricated in the laboratory using untreated or alkali treated white birch outer bark particles as substitute material. These particles were resinated successively with three percentages of phenol-formaldehyde resin. Overall, the results of this study clearly demonstrate that the panels could be manufactured using up to $45 \%$ of the proposed substitute material and still maintain the required mechanical and physical properties.

- Alkali treatment was used to remove natural wax from bark particles surface which hinders resin adhesion. This treatment negatively affected mechanical and physical properties of finished panels and the variation of phenol-formaldehyde resin percentage in the bark particles significantly affected only their hardness.

- Panel with untreated bark particles in the surface layers, resinated with 5\% phenol-formaldehyde resin was selected as the best with the help of a statistical analysis carried out in a factorial complete block design, especially from the dimensional stability criterion.
\end{abstract}

Résumé - Propriétés des panneaux d'écorce externe de bouleau blanc (Betula papyrifera) avec renfort de particules grossières de bois dans la couche médiane.

- L'objet de cette étude est de substituer la matière première traditionnelle dans les couches couvrantes des panneaux de particules conventionnelles par les particules hydrophobes d'écorce externe de bouleau blanc (Betula papyrifera) qui peuvent aider à améliorer la stabilité dimensionnelle des panneaux mixtes produits et ainsi permettre d'alléger la pénurie de la matière première d'une manière rentable.

- Les panneaux de particules mixtes ont été fabriqués à l'échelle du laboratoire en utilisant les particules d'écorce externe de bouleau blanc non traitées ou traitées à la soude comme matériel de substitution. Ces particules ont été encollées successivement avec trois pourcentages de colle phénolformaldéhyde. Les résultats de cette étude démontrent d'un bout à l'autre que les panneaux pourraient être fabriqués en utilisant jusqu'à $45 \%$ de matière de substitution proposée et maintenir toujours les exigences des propriétés mécaniques et physiques.

- Le traitement à la soude a été utilisé afin d'enlever la cire naturelle de la surface des écorces qui empêche l'adhésion de la colle. Ce traitement a affecté négativement les propriétés mécaniques et physiques des panneaux produits et la variation du pourcentage de la colle phénol-formaldéhyde dans les particules d'écorce a affecté leur dureté de manière hautement significative.

- Le panneau avec les particules d'écorce non traitées dans les couches couvrantes et encollées avec $5 \%$ de phénol-formaldéhyde a été sélectionné comme le meilleur à l'aide d'une analyse statistique faite dans un plan factoriel en blocs complets, en se basant sur le critère de la stabilité dimensionnelle.

\footnotetext{
*Corresponding author: Bernard.Riedl@sbf.ulaval.ca
} 


\section{INTRODUCTION}

The quantity of white birch bark produced in 2005 in Quebec, Canada was approximately 96000 tons (Anonymous, 2005). Smith and Kozak (1967) found out that bark represents 9 to $24 \%$ of corresponding tree volume depending on species and diameter. Barks are mainly used for energy production in Quebec. White birch (Betula papyrifera) bark has two different parts: the outer bark has a paper-like texture with several layers; the inner bark has a granular form. The acidity $(\mathrm{pH}$ value and buffering capacity) of these two parts of white birch bark is also different (Pedieu et al., 2008). Thus, in the case of this study, they were systematically separated by screening before being used in the manufacture of mixed particleboards. The use of white birch outer bark in canoes is an example of its oldest use by the first nations in Canada. This use confirms its hydrophobic characteristic which can be made more beneficial by using it in the outer layers of 3- layer mixed panels in order to improve the dimensional stability of produced mixed panels. With an increasing demand of wood composite products wood will become less available and the best alternative will be to use value-added products like barks or agricultural and recycled residues (Kozlowski and Helwig, 1998; Roffael et al., 2004; Sampathrajan et al., 1992). For instance, Boquillon et al., (2004) investigated the properties of wheat straw particleboards bonded with different types of resin. In the same way Nemli et al. (2006) evaluated the mechanical and physical properties as well as the decay resistance of particleboards made from particles impregnated with Pinus brutia bark extractives. Interest has burgeoned in combining wood and other raw material into composite products that can utilize recycled materials (Youngquist et al., 1993a; 1993b; 1994). If it is known that bark has some advantages over wood when used as a mulch or in other soil amelioration approaches (Allison, 1965), it is not the same situation with its utilization in particleboards manufacture because of poor mechanical properties of those particleboards (Blanchet, 2000; Villeneuve, 2004). Many researchers used barks alone or combined them with wood to manufacture different types of panels such as particleboards (Dost, 1971; Lehmann and Geimer, 1976; Maloney, 1973; Volz, 1973; Wisherd and Wilson, 1979), hardboard (Woodson, 1975), medium density fiberboard (Chow, 1976; Xing et al., 2006) and oriented strand board (Roffael et al., 2004). In the case of this study, the white birch outer bark particles were used for panels manufacture at the laboratory scale. It is well known from the studies of Lundqvist and Back (1976) that the outer birch bark is not a structural material like wood, because it is made up of less than $4 \%$ cellulose. During the preliminary tests single layer panels with outer white birch bark particles were fabricated but their mechanical properties were lower than the requirements of the standard of M-1 grade panels for interior use. Only the thickness swelling after $24 \mathrm{~h}$ water immersion of those panels was good (less than $3 \%$ ), confirming the hydrophobic characteristic of outer white bark. Lundqvist and Back (1976) suggested in their studies that, since it is impossible to produce panels with $100 \%$ outer bark particles of birch meeting the standard requirements of M-1 grade panels, therefore, it is advisable to use them rather in the core layer of mixed panels with wood particles in the surface layers. This suggestion was applied during the preliminary tests, where two sizes of white birch bark particles were used in the core of mixed panels with wood particles in the surface layers. The first panel was fabricated using white birch outer bark particles of sizes between $2 \mathrm{~mm}$ and $6 \mathrm{~mm}$ in the core layer and the second was fabricated using bark particles of sizes between $0.25 \mathrm{~mm}$ and $1 \mathrm{~mm}$ in the core layer. The modulus of rupture (MOR) and the modulus of elasticity (MOE) of these panels didn't meet the standard requirements. The internal bond (IB) of panel with bark particles of sizes were between $2 \mathrm{~mm}$ and $6 \mathrm{~mm}$ was very low but that of panel with bark particles sizes between $0.25 \mathrm{~mm}$ and $1 \mathrm{~mm}$ was even higher than that of the standard value for M-1 grade panels. From these results it was obvious that white birch outer bark particles should be used rather in the surface layers of mixed panels and reinforced by coarse wood particles in the core layer, in order to improve their MOR and MOE. These types of panel can be used as sub-flooring or wallboard because outer bark particles of birch in their surface layers will help protecting them from any dimensional changes. The alkali treatment is done to increase the surface energy of bark particles which increases their wettability and facilitate their interfacial bonding.

The objectives of this study were to (1) measure the mechanical and physical properties of all manufactured mixed panels and compare them with those of wood reference panel; (2) assess the effect of alkali treatment of white birch bark particles as well as the variation's effect of phenol-formaldehyde (PF) resin percentage used to resinate them on the panels' properties; (3) select the best mixed panel with the help of statistical analysis carried out in a randomized complete block design.

\section{MATERIAL AND METHODS}

\subsection{Preparation of inner bark particles of white birch}

The barks were obtained from sawmill Thomas Louis Tremblay Inc. of Ste-Monique located in the north of Quebec, Canada. The proportion of sapwood in those barks was approximately $8 \%$ of their oven-dried weight. They were dried at room temperature for ten days to $9 \%$ moisture content and then reduced to chips with the help of hammer mill (Jeffrey) and Pallmann'mill. The inner bark was separated from the outer bark by screening. The dust was eliminated by the means of a $0.25 \mathrm{~mm}$ mesh vibrating horizontal screen. Finally, the size of obtained outer bark particles was between $0.25 \mathrm{~mm}$ and $1 \mathrm{~mm}$. They were dried to $3 \%$ moisture content in a laboratory-type dryer. Coarse wood particles (a mixture of spruce, fir and pine) were obtained from TAFISA in Lac-Mégantic, Canada.

\section{2. $\mathrm{NaOH}$ treatment of bark particles}

$\mathrm{NaOH}$ water solution was used to remove the wax from bark particles surface and to alter suberin layers covering this surface and behaving like Teflon in order to facilitate their wettability during the blending stage and to improve the interfacial bonding with PF resin. 
During the preliminary tests, a $1 \% \mathrm{NaOH}$ solution was used for the treatment with the ratio: $2 \mathrm{~g}$ of dry bark in $100 \mathrm{~mL}$ of $1 \% \mathrm{NaOH}$ solution and heated for $30 \mathrm{~min}$ as required by the standard. But it was a failure, because bark particles used were totally dissolved. An alternative solution was to decrease the concentration of $\mathrm{NaOH}$ in the solution and to carry out an empirical cold temperature treatment. Thus, $6 \mathrm{~kg}$ of bark particles were weighed and put in a rotary mixer, $200 \mathrm{~g}$ of pure $\mathrm{NaOH}$ prior dissolved in one litre water were used to spray them. Then, the mixer was left in rotation for $10 \mathrm{~min}$ for the best impregnation of bark particles. Finally they were removed from the mixer and dried initially at room temperature for three days and thereafter in a laboratory-type dryer up till $3 \%$ moisture content, before being used in the particleboards manufacture. Wood particles and untreated bark particles were also dried in the same dryer up till 3\% moisture content. The sizes of particles used to manufacture panels were as follows: coarse wood particles used in all core layers of all panels, between $2 \mathrm{~mm}$ and $6 \mathrm{~mm}$; fine wood particles used in the surface layers of reference panel, between $0.25 \mathrm{~mm}$ and $2 \mathrm{~mm}$; bark particles used in the surface layers of all mixed panels, between $0.25 \mathrm{~mm}$ and $1 \mathrm{~mm}$.

\subsection{Experimental design}

The preliminary tests enabled to design the manufacture of 3-layer mixed panel with outer bark particles of white birch in the surface layers and coarse wood particles in the core layer. The target density was $800 \mathrm{kgm}^{-3}$ and the nominal thickness $8 \mathrm{~mm}$. A factorial design with two manufacturing factors in a complete block design (CBD) was used. Blocking is used to prevent nuisance factor from known and controllable sources of variability (Montgomery, 2005). In the case of this study, the nuisance factor for instance was the day that panels were fabricated, because the weight of particles used to manufacture the same type of panel can slightly vary randomly each time it is fabricated. The first factor of the experiment was the type of raw material used in the surface layers. This factor has two levels: (1) untreated bark particles; (2) alkali treated bark particles. This factor is qualitative. The second factor was the percentage of PF resin used to bond bark particles with three levels: (1) $5 \%$ : (2) $6.5 \%$; (3) $8 \%$ (by weight of dry bark particles in the surface layers). This factor is quantitative with equal spacing $(1.5 \%)$. The choice of these three percentages was made to assess the impact of a PF resin increase in bark particles on the properties of manufactured mixed panels. Thus, the total treatment number (the term treatment in this context is different from alkali treatment, it rather means the operations carried out to obtain the six panel types) per block resulting from the multiplication of both factors levels is $2 \times 3=6$ treatments. Each panel considered as an experimental unit was replicated four times to give a total of 24 panels. The identification of the six treatments corresponding to the six panel types per block is presented in Table I. The experimental design was set up with the help of plan procedure of SAS software to fulfill the randomisation principle that eliminates subjectivity and ensure the independency of errors (Montgomery, 2005). Three-layer wood reference panels were also fabricated and their properties were compared with those of mixed panels using the least significance difference test (LSD) in a complete random design (CRD).

\subsection{Manufacturing parameters}

The board size (width $\times$ length $\times$ thickness) was $0.75 \times 0.75 \times$ $0.009 \mathrm{~m}$ (non-sanded) and $0.75 \times 0.75 \times 0.008 \mathrm{~m}$ (sanded) and the tar-
Table I. Identification and description of particleboard types.

\begin{tabular}{ccl}
\hline$\#$ & Types & \multicolumn{1}{c}{ Description } \\
\hline 1 & $\mathrm{P}_{5 \%}$ & $\begin{array}{l}\text { Particleboard with untreated bark particles in the face } \\
\text { layers bonded with } 5 \% \text { (by weight of oven-dry bark } \\
\text { particles) PF resin }\end{array}$ \\
2 & $\mathrm{P}_{6.5 \%}$ & $\begin{array}{l}\text { Particleboard with untreated bark particles in the face } \\
\text { layers bonded with } 6.5 \% \text { (by weight of oven-dry bark } \\
\text { particles) PF resin }\end{array}$ \\
3 & $\mathrm{P}_{8 \%}$ & $\begin{array}{l}\text { Particleboard with untreated bark particles in the face } \\
\text { layers bonded with } 8 \% \text { (by weight of oven-dry bark } \\
\text { particles) PF resin }\end{array}$ \\
4 & $\mathrm{P}_{s-5 \%}$ & $\begin{array}{l}\text { Particleboard with alkali treated bark particles in the face } \\
\text { layers bonded with } 5 \% \text { (by weight of oven-dry bark } \\
\text { particles) PF resin }\end{array}$ \\
5 & $\mathrm{P}_{s-6.5 \%}$ & $\begin{array}{l}\text { Particleboard with alkali treated bark particles in the face } \\
\text { layers bonded with } 6.5 \% \text { (by weight of oven-dry bark } \\
\text { particles) PF resin }\end{array}$ \\
& & $\begin{array}{l}\text { Particleboard with alkali treated bark particles in the face } \\
\text { layers bonded with } 8 \% \text { (by weight of oven-dry bark } \\
\text { particles) PF resin }\end{array}$ \\
\hline
\end{tabular}

get density of all panels was $800 \mathrm{~kg} / \mathrm{m} 3$. The shelling ratio (defined as the face thickness to the total panel thickness (Nemly and Çolakoglu, 2005)) of all mixed panels and reference panel were respectively 0.45 and 0.40 , the compaction ratio $(\mathrm{Cr}=$ mat thickness/particleboard thickness) of all mixed panels and reference panel were respectively $(45 \mathrm{~mm} / 9 \mathrm{~mm})=5$ and $(32 \mathrm{~mm} / 9 \mathrm{~mm})=3.5$. The resin used was phenol-formaldehyde (PF) (Bordon Casco-resin, solid content: 52\%) The percentage of PF used (based on oven-dry weight of particles used) was respectively $6 \%$ in the coarse wood particles used in the core layers of all panels, $7 \%$ in the fine wood particles used in the surface layers of reference panel, $5,6.5$ or $8 \%$ in the fine outer bark particles of white used in the surface layers of mixed panels. The percentage of wax used (based on oven-dry weight of particles used) was respectively $0.5 \%$ in the coarse wood particles used in the core layers of all panels, $1 \%$ in the fine wood particles used in the surface layers of reference panel. No wax was added to fine outer bark particles of white used in the surface layers of mixed panels because they are already waxy. The press platen temperature and the press pressure were respectively $180{ }^{\circ} \mathrm{C}$ and $180 \mathrm{kPa}$. The press closing time was $26 \mathrm{~s}$, the curing time $4 \mathrm{~min}$ and the press opening time $1 \mathrm{~min}$ in three steps.

\subsection{Particleboards manufacture and tests}

The particles for each panel type were mixed in a rotating-drum mixer for $5 \mathrm{~min}$. The panel was manually formed in a frame prior to its hot pressing. Test samples were prepared based on ASTM D-103799 specifications and the result of each test was compared with the value of ANSI A208.1-1999. The panels were conditioned at a temperature of $20{ }^{\circ} \mathrm{C}$ and $65 \%$ relative humidity until they reached their equilibrium moisture content ( 4 weeks). Then, they were sanded with 120 grit sand to $8 \mathrm{~mm}$ final thickness before any test was carried out. The particleboard flooring product grade requirement is summarized in Table II Photos of manufactured panels are presented in Figure 1. The number of specimens used for each property was as follows: 4 specimens of $242 \times 75 \mathrm{~mm}$ per panel ( 2 in length and 2 in width) for the modulus of elasticity (MOE) and the modulus of rupture (MOR); 6 specimens of $50 \times 50 \mathrm{~mm}$ per panel for the internal bond (IB); 
Table II. Particleboard flooring product grade requirements (ANSI 208.1-1999 particleboard).

\begin{tabular}{llllllll}
\hline Grade & $\begin{array}{l}\text { MOR } \\
(\mathrm{MPa})\end{array}$ & $\begin{array}{l}\text { MOE } \\
(\mathrm{MPa})\end{array}$ & $\begin{array}{l}\text { IB } \\
(\mathrm{MPa})\end{array}$ & $\begin{array}{l}\text { Hardness } \\
(\mathrm{N})\end{array}$ & TS & $\begin{array}{l}\text { LE } \\
(\%)\end{array}$ & $\begin{array}{l}\text { F M E } \\
(\mathrm{ppm})\end{array}$ \\
\hline PBU & 11.0 & 1725 & 0.40 & 2225 & $1.6 \mathrm{~mm}$ & 0.35 & 0.20 \\
D-2 & 16.5 & 2750 & 0.55 & 2225 & $8 \%$ & 0.30 & 0.20 \\
D-3 & 19.5 & 3100 & 0.55 & 2225 & $8 \%$ & 0.30 & 0.20 \\
\hline
\end{tabular}

$\mathrm{PBU}=$ Underlayment; $\mathrm{D}=$ manufactured home decking; $\mathrm{MOR}=$ modulus of elasticity; MOR = modulus of rupture; $\mathrm{IB}=$ internal bond; TS = thickness swell; $\mathrm{LE}=$ linear expansion: $\mathrm{FME}=$ formaldehyde maximum emission.

Mixed particleboard with coarse wood particles in the core layer and outer bark particles of white birch in the surface layers

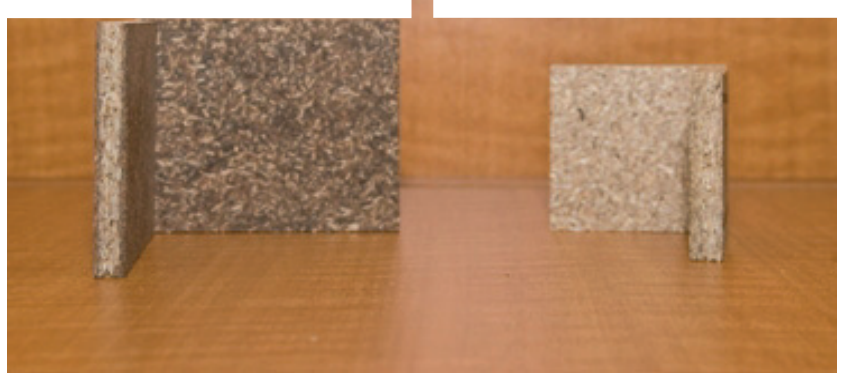

Figure 1. Samples of manufactured particleboards: side and front views.

3 specimens of $150 \times 75 \mathrm{~mm}$ per panel for the hardness; 2 specimens of $150 \times 150 \mathrm{~mm}$ per panel for the Thickness swelling (TS); 4 of $300 \times 75 \mathrm{~mm}$ per panel ( 2 in length and 2 in width) for the linear expansion (LE).

\section{RESULTS AND DISCUSSION}

\subsection{Density profile}

The density profiles of panels with untreated bark particles in the face layers are similar and those of panels with alkali treated bark particles in the surface layers are also similar. Thus, only one profile representing each group was selected and drawn together with that of wood reference panel in Figure 2 for comparison. Figure 2 shows that, the density profile of wood reference panel is above those of mixed particleboards with respectively untreated and alkali treated bark particles in their face layers. Thus, the association of outer bark particles of white birch with coarse wood particles leads to a decrease of manufacture particleboards average density. The density profile of particleboard with alkali treated bark particles in the surface layers is above that of particleboard with untreated bark particles. Thus, alkali treatment of bark particles used in the face of mixed particleboard increases its average density because alkali treated bark particles are more compressible and are bonded better with PF resin. By comparing density profile of mixed particleboards with that of wood reference particleboard, it was noticed that, the substitution of fine wood particles in the surface layers by either untreated or treated outer bark particles of white birch leads to a decrease of the minimal density value and to a flattening-out improvement of density profile in the core layer of manufactured mixed particleboards.

\subsection{Results of physical and mechanical properties}

These results are presented in Table III. The mechanical and physical properties of manufactured particleboards were found to comply with grade PBU of particleboard flooring product as stated by ANSI (Tab. II). The values of mechanical properties of all mixed particleboards are less than those of wood reference particleboard because bark particles used in the face are not a structural material like wood. Alkali treatment of outer bark particles of white birch lowered the mechanical properties of manufactured mixed particleboards because part of the suberin (surface wax-like material) was destroyed and removed by saponification during the alkali treatment in such a way that the structure of bark particles became weak (Fengel and Wegener, 1989). An increase of PF resin in the untreated bark particles led to a decrease of MOE, MOR and IB of mixed manufactured particleboards because PF resin has approximately $20 \%$ alkali content that saponified suberin of bark particle and weakened its structure (Fengel and Wegener, 1989). Hergert (1958), Holloway (1972) and Swan (1968) have all analysed the saponified suberin mixture and found out that suberin has a polyester structure composed mainly of long chain fatty acids with variation of the composition depending on the species. The thickness swelling and linear expansion of mixed particleboard were lower than those of reference panel. But the alkali treatment of bark particles used negatively affected the thickness swelling and the linear expansion of mixed particleboards because this treatment has increased a lot the wettability of bark particles.

\subsection{Analysis of variance}

The summary of variance analysis (ANOVA) is presented in Table IV. The F values of treatments of all properties tested were significant but the $\mathrm{F}$ value associated to blocking for each property tested was not significant. It is a proof that, there was no blocking effect. The type of material (untreated and alkali treated bark particles) used in the surface layers of manufactured mixed panels had a highly significant effect on all tested properties. It is therefore a proof that there is a significant difference between untreated and alkali treated bark particles used respectively in the face layers of mixed particleboards. The variation of PF resin percentage in the bark particles didn't have any significant effect on MOE, MOR, IB, TS and LE, but its effect on hardness was highly significant. Significant interactions were interpreted with the help of interaction plots (Figs. 3, 4, 5, and 6). The standard errors (S.E.) 


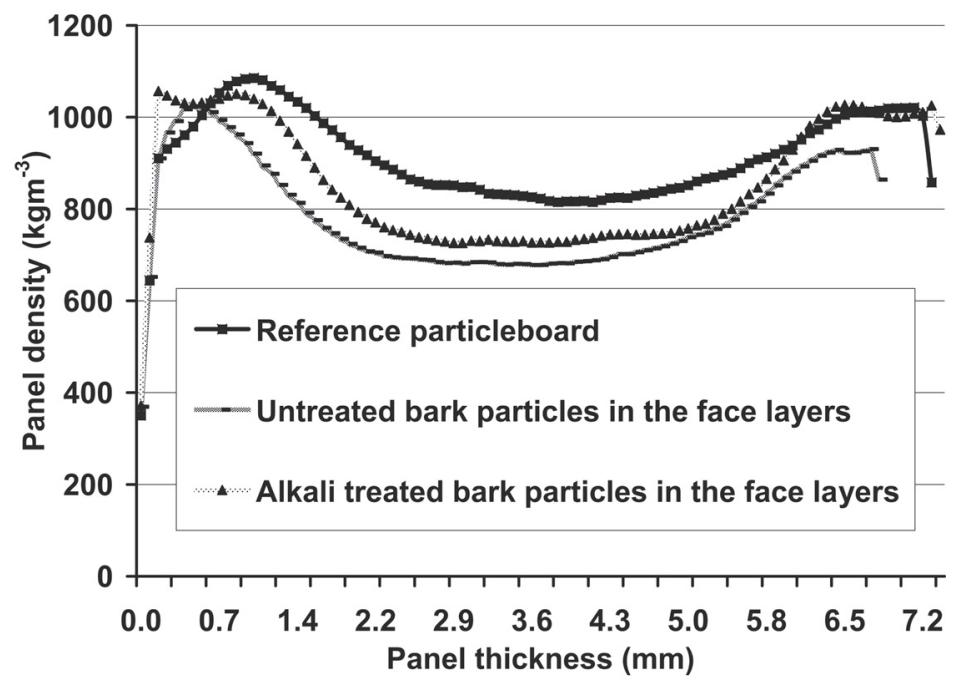

Figure 2. Typical density profiles of reference particleboard made from $100 \%$ wood particles and mixed particleboards with respectively untreated and treated outer bark particles of white birch in the surface layers.

Table III. Results of mechanical and physical properties: MOE = modulus of elasticity; MOR = modulus of rupture; IB = internal bond; Hard = hardness; TS = thickness swell; $\mathrm{LE}=$ linear expansion; $(\mathrm{N})=$ Newton.

\begin{tabular}{|c|c|c|c|c|c|c|c|}
\hline \multicolumn{2}{|c|}{ Factorial design } & \multicolumn{6}{|c|}{ Mechanical and physical properties } \\
\hline Bark & $\begin{array}{c}\mathrm{PF} \\
(\%) \\
\text { used to bond } \\
\text { bark particles }\end{array}$ & $\begin{array}{l}\text { MOE } \\
(\mathrm{MPa})\end{array}$ & $\begin{array}{l}\text { MOR } \\
(\mathrm{MPa})\end{array}$ & $\begin{array}{c}\mathrm{IB} \\
(\mathrm{MPa})\end{array}$ & $\begin{array}{c}\text { Hardness } \\
(\mathrm{N})\end{array}$ & $\begin{array}{l}\mathrm{TS} \\
(\%)\end{array}$ & $\begin{array}{l}\mathrm{LE} \\
(\%)\end{array}$ \\
\hline \multirow{4}{*}{$\begin{array}{l}\text { Non } \\
\text { treated } \\
\text { barks }\end{array}$} & 5 & $\begin{array}{l}2212 \\
(68)\end{array}$ & $\begin{array}{l}25.2 \\
(0.7)\end{array}$ & $\begin{array}{c}1.41 \\
(0.16)\end{array}$ & $\begin{array}{l}4912 \\
(414)\end{array}$ & $\begin{array}{c}3.2 \\
(0.8)\end{array}$ & $\begin{array}{c}0.15 \\
(0.01)\end{array}$ \\
\hline & 6.5 & $\begin{array}{r}2182 \\
(84)\end{array}$ & $\begin{array}{l}24.8 \\
(0.8)\end{array}$ & $\begin{array}{c}1.45 \\
(0.14)\end{array}$ & $\begin{array}{l}5725 \\
(533)\end{array}$ & $\begin{array}{c}5.6 \\
(1.0)\end{array}$ & $\begin{array}{c}0.16 \\
(0.01)\end{array}$ \\
\hline & 8 & $\begin{array}{l}2164 \\
(144)\end{array}$ & $\begin{array}{c}24 \\
(2.2)\end{array}$ & $\begin{array}{c}1.14 \\
(0.13)\end{array}$ & $\begin{array}{l}5002 \\
(305)\end{array}$ & $\begin{array}{c}8.3 \\
(3.2)\end{array}$ & $\begin{array}{c}0.15 \\
(0.02)\end{array}$ \\
\hline & 5 & $\begin{array}{l}1945 \\
(190)\end{array}$ & $\begin{array}{l}17.5 \\
(1.3)\end{array}$ & $\begin{array}{c}1.12 \\
(0.08)\end{array}$ & $\begin{array}{l}4092 \\
(215)\end{array}$ & $\begin{array}{l}15.3 \\
(0.7)\end{array}$ & $\begin{array}{c}0.27 \\
(0.03)\end{array}$ \\
\hline \multirow{2}{*}{$\begin{array}{l}\text { Alkali } \\
\text { treated } \\
\text { barks }\end{array}$} & 6.5 & $\begin{array}{l}1805 \\
(106)\end{array}$ & $\begin{array}{l}17.4 \\
(1.7)\end{array}$ & $\begin{array}{c}1.04 \\
(0.08)\end{array}$ & $\begin{array}{l}4639 \\
(217)\end{array}$ & $\begin{array}{l}14.5 \\
(1.0)\end{array}$ & $\begin{array}{c}0.26 \\
(0.01)\end{array}$ \\
\hline & 8 & $\begin{array}{l}2185 \\
(121)\end{array}$ & $\begin{array}{l}22.3 \\
(2.2) \\
\end{array}$ & $\begin{array}{c}1.11 \\
(0.22) \\
\end{array}$ & $\begin{array}{l}5236 \\
(230) \\
\end{array}$ & $\begin{array}{c}8.4 \\
(1.6) \\
\end{array}$ & $\begin{array}{r}0.27 \\
(0.02) \\
\end{array}$ \\
\hline
\end{tabular}

* Numbers in brackets are standard deviations.

associated with those interactions were computed using the following formula: S.E. $=\sqrt{\frac{M . S . E}{r \times n}}$ where M.S.E is the mean square of experimental error of ANOVA, $r$ the number of replicate and $n$ the number of hidden replicates (Collin, 2003). In the case of this study $n=1$ because there are only two factors. Results of S.E. are presented in Table VI. The S.E. is repre-
Table IV. Summary of variance analysis (ANOVA): MOE = modulus of elasticity; $\mathrm{MOR}=$ modulus of rupture; $\mathrm{IB}=$ internal bond; Hard = hardness; TS = thickness swell; LE = linear expansion.

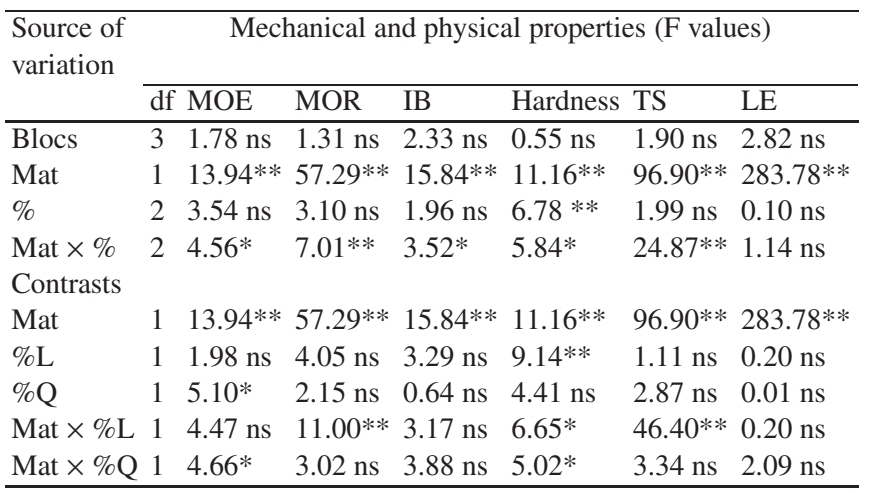

$\mathrm{df}=$ Degree of freedom; mat $=$ type of material in the face layers; $\%=$ percentage of $\mathrm{PF}$ resin used to bond bark particles; $\% \mathrm{~L}=$ linear effect of $\% ; \% \mathrm{Q}=$ quadratic effect of $\%$; Mat $\times \% \mathrm{~L}=$ interaction between Mat and $\% \mathrm{~L} ;$ Mat $\times \% \mathrm{Q}=$ interaction between Mat and $\% \mathrm{Q} ; \mathrm{ns}=$ non-significant; * significant at $95 \%$ but not significant at $99 \%$; ** significant at $99 \%$ or highly significant.

sented on the interaction plots of Figures 3, 4, 5 and 6 by bars whose length is two times the standard error value. These bars overlap where the interaction is not significant. From Figure 3, it is noticeable that, there are significant differences between MOE of panels with untreated bark particles bonded with respectively 5 and $6.5 \%$ PF resin and corresponding panels with alkali treated bark particles. But the difference is not significant between panel with untreated bark particles bonded with $8 \% \mathrm{PF}$ resin and the corresponding panel with alkali treated bark particles. The highest value of MOE is reached when untreated bark particles bonded with 5\% PF resin are used. In Figure 4 it is clear that, there is a significant difference between 


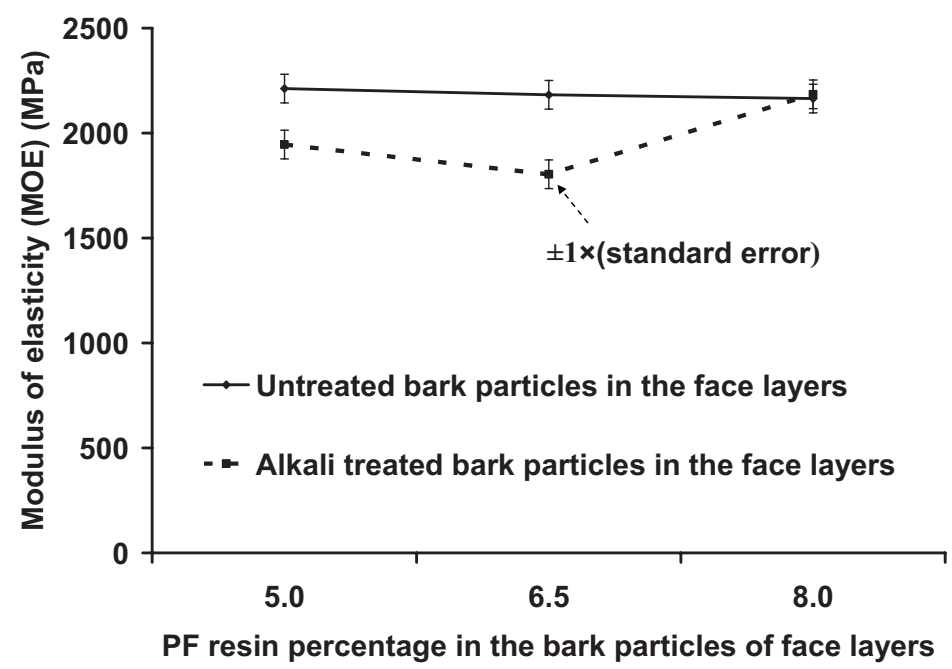

Figure 3. Interaction plots between the type of material in the panel core layer and the phenol-formaldehyde percentage used to resinate them for the modulus of elasticity.

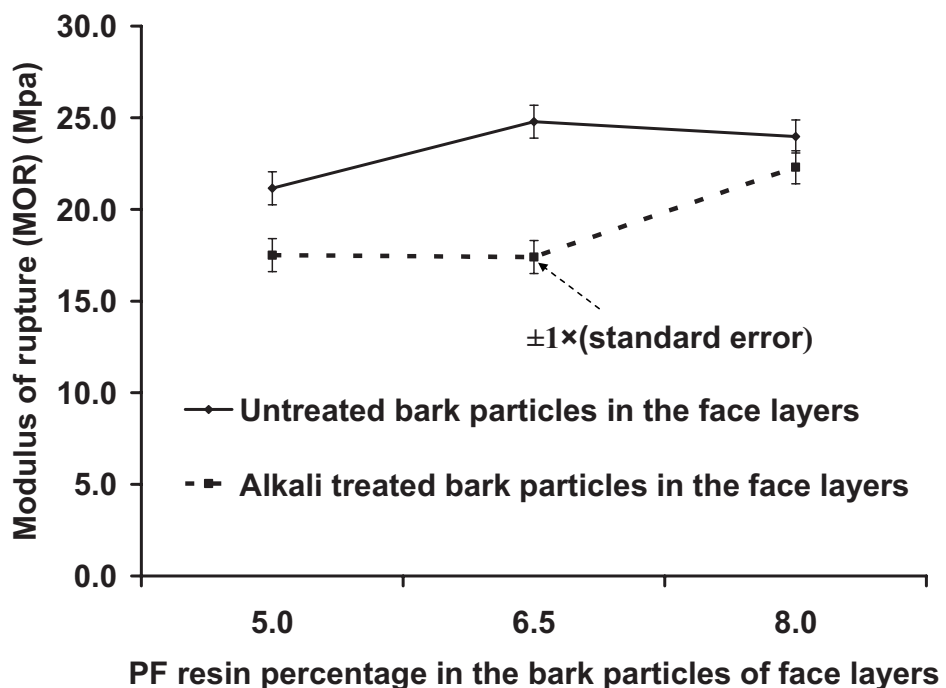

Figure 4. Interaction plots between the type of material in the panel core layer and the phenol-formaldehyde percentage used to resinate them for the modulus of rupture.

the MOR of panels with untreated bark particles bonded with respectively 5, 6.5 and $8 \% \mathrm{PF}$ resin and corresponding panels with alkali treated bark particles. The highest value of MOR is reached when untreated bark particles bonded with $6.5 \% \mathrm{PF}$ resin are used. Figure 5 shows that the hardness of mixed panels with untreated bark particles bonded respectively with 5 and $6.5 \% \mathrm{PF}$ resin are significantly different from corresponding panels with alkali treated bark particles. But the there is no significant difference between panel with untreated bark particles bonded with $8 \%$ PF resin and the corresponding panel with alkali treated bark particles. The highest value of hardness is reached when untreated bark particles bonded with 6.5\% PF resin are used. From Figure 6 the following interpretation can be done: there are significant differences between TS of panels with untreated bark particles bonded with respectively 5 and $6.5 \%$ PF resin and corresponding panels with al- kali treated bark particles. But the difference is not significant between panel with untreated bark particles bonded with $8 \%$ PF resin and the corresponding panel with alkali treated bark particles. The best and lowest value of TS is obtained when untreated bark particles bonded with 5\% PF resin are used.

\subsection{Result of comparison test using LSD (least significant difference) test}

Tested panels were also compared with reference panel fabricated only with wood particles and the results are presented in Table VII. The least significant difference test (LSD) was used for the comparison. Panel sharing the same letter with the reference for a given property is not significantly different from this latter. Thus, MOE and MOR of reference panel 


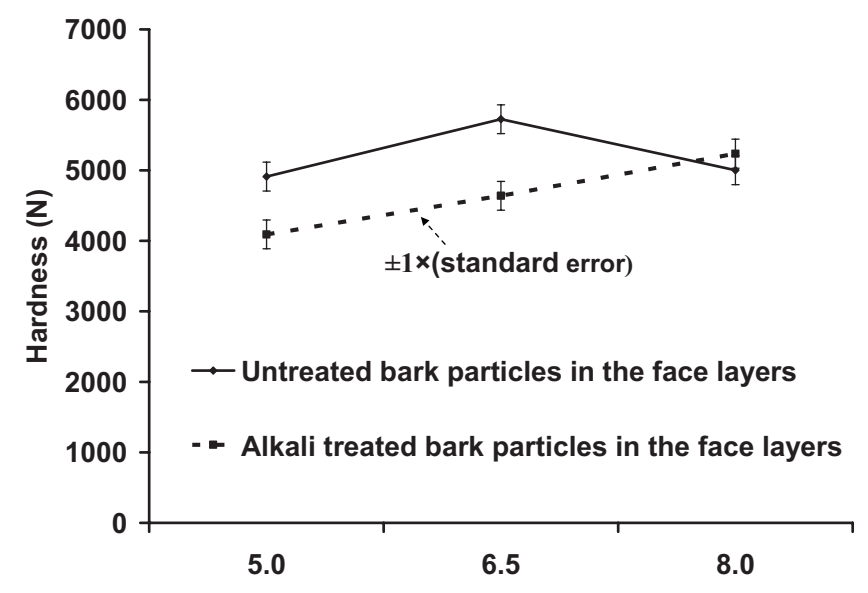

PF resin percentage in the bark particles of face layers

Figure 5. Interaction plots between the type of material in the panel core layer and the phenol-formaldehyde percentage used to resinate them for the hardness.

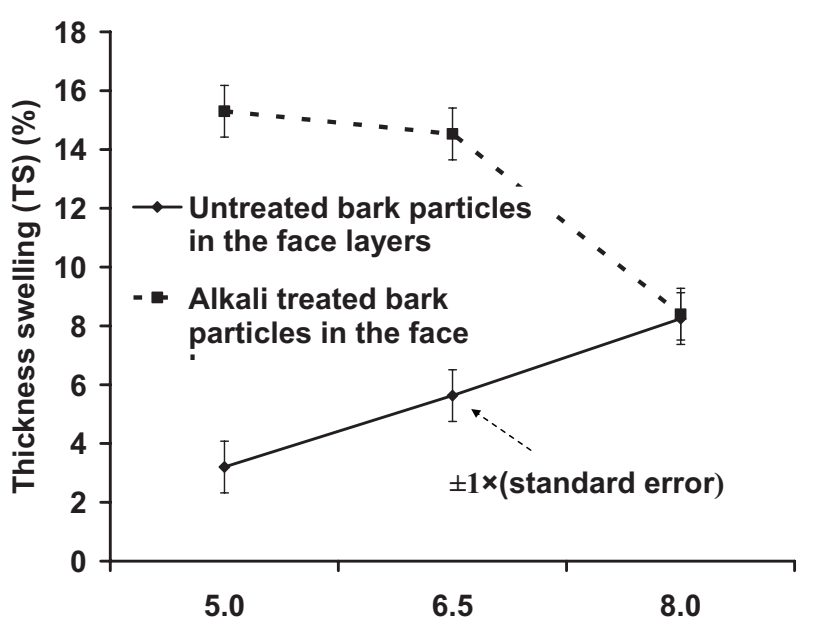

PF resin percentage in the bark particles of face layers

Figure 6. Interaction plots between the type of material in the panel core layer and the phenol-formaldehyde percentage used to resinate them for the thickness swelling.

Table V. Standard error (S.E.) associated with significant interactions.

\begin{tabular}{lllll}
\hline & \multicolumn{4}{c}{ S.E. associated with significant interactions } \\
\cline { 2 - 5 } Interactions & MOE & MOR & Hard & TS \\
\hline Mat $\times \%$ & 68.2 & 0.9 & 204.3 & 0.88 \\
\hline
\end{tabular}

MOE $=$ Modulus of rupture MOR $=$ modulus of elasticity , hard $=$ hard ness; TS $=$ thickness swell, Mat $=$ type of material.

don't share their "a" letter with any mixed panel. It is a proof that MOE and MOR of manufactured mixed particleboards are significantly lower than those of reference panel. The internal bonds (IB) of mixed panels with untreated bark particles in the face and respectively bonded with 5 and $6.5 \% \mathrm{PF}$ resin are not significantly different from that of reference panel. The hardness of mixed panel with untreated bark particles bonded with $6.5 \% \mathrm{PF}$ resin and that of mixed panel with alkali treated bark
Table VI. Comparison of mixed panels with the reference panel ( $100 \%$ wood particles) with the help of LSD (least significant difference) test.

\begin{tabular}{lcccccc}
\hline \multirow{2}{*}{$\begin{array}{l}\text { Types of } \\
\text { panel }\end{array}$} & \begin{tabular}{c} 
MOE \\
\cline { 2 - 7 }
\end{tabular} & $\begin{array}{c}\text { MOR } \\
(\mathrm{MPa})\end{array}$ & $\begin{array}{c}\mathrm{IB} \\
(\mathrm{MPa})\end{array}$ & $\begin{array}{c}\text { Hard } \\
(\mathrm{N})\end{array}$ & $\begin{array}{c}\mathrm{TS} \\
(\%)\end{array}$ & $\begin{array}{c}\text { LE } \\
(\%)\end{array}$ \\
\hline $\mathrm{P}_{5 \%}$ & $2212 \mathrm{~b}$ & $25.1 \mathrm{~b}$ & $1.41 \mathrm{a}$ & $4911 \mathrm{bc}$ & $3.2 \mathrm{~d}$ & $0.14 \mathrm{~b}$ \\
$\mathrm{P}_{6.5 \%}$ & $2182 \mathrm{~b}$ & $24.8 \mathrm{~b}$ & $1.45 \mathrm{a}$ & $5724 \mathrm{a}$ & $5.6 \mathrm{~cd}$ & $0.15 \mathrm{~b}$ \\
$\mathrm{P}_{8 \%}$ & $2164 \mathrm{~b}$ & $23.9 \mathrm{~b}$ & $1.14 \mathrm{~b}$ & $5002 \mathrm{bc}$ & $8.2 \mathrm{bc}$ & $0.14 \mathrm{~b}$ \\
$\mathrm{P}_{s-5 \%}$ & $1945 \mathrm{bc}$ & $17.5 \mathrm{c}$ & $1.11 \mathrm{~b}$ & $4091 \mathrm{~d}$ & $15.3 \mathrm{a}$ & $0.27 \mathrm{a}$ \\
$\mathrm{P}_{s-6.5 \%}$ & $1804 \mathrm{c}$ & $17.4 \mathrm{c}$ & $1.04 \mathrm{~b}$ & $4639 \mathrm{~cd}$ & $14.5 \mathrm{a}$ & $0.26 \mathrm{a}$ \\
$\mathrm{P}_{s-8 \%}$ & $2185 \mathrm{~b}$ & $22.3 \mathrm{~b}$ & $1.11 \mathrm{~b}$ & $5236 \mathrm{ab}$ & $8.4 \mathrm{~b}$ & $0.26 \mathrm{a}$ \\
$\mathrm{P}_{\text {reference }}$ & $3972 \mathrm{a}$ & $29.4 \mathrm{a}$ & $1.63 \mathrm{a}$ & $5633 \mathrm{a}$ & $16.8 \mathrm{a}$ & $0.26 \mathrm{a}$ \\
\hline
\end{tabular}

Means with the same letter are not significantly different. MOE $=$ Modulus of elasticity; MOR = modulus of rupture; IB = internal bond; hard = hardness; TS = thickness swell; $\mathrm{LE}=$ linear expansion.

Table VII. Regression.

\begin{tabular}{lllllll}
\hline Regression & MOE & MOR & IB & Hard & TS & LE \\
& versus & versus & versus & versus & versus & versus \\
& density & density & density & density & density & density \\
\hline F Value & $12.41^{*}$ & $19.27^{*}$ & $0.073 \mathrm{~ns}$ & $3.000 \mathrm{~ns}$ & $34.070^{* *}$ & $0.009 \mathrm{~ns}$ \\
$R^{2}$ & 0.76 & 0.83 & 0.48 & 0.43 & 0.89 & 0.45 \\
\hline
\end{tabular}

MOE $=$ Modulus of elasticity MOR = modulus of rupture; IB = internal bond; hard = hardness; TS = thickness swell; LE = linear expansion.

particles bonded with $8 \%$ PF resin are not significantly different from that of reference panel. The TS and LE of mixed panels with untreated bark particles bonded with 5\% PF resin have the best and lowest values which are significantly different from those of reference panel.

\subsection{Regression}

Regression was done in order to find the cause of significant variations observed in the measurement of some properties. The density of samples used was chosen as the most probable cause of these variations. The results of this investigation presented in Table VIII show that there is a significant $F$ value for regression for the following dependant variables: MOE, MOR and TS. The independent variable is the density of samples used. In the case of IB, hardness and LE, F value is not significant for the regression: it therefore means that, the variations observed in the measurement of these properties (dependent variables) are independent of the samples density used. But the variation observed in the measurement of MOE, MOR and TS can be respectively explained at $76 \%\left(R^{2}=0.76\right), 82 \%$ $\left(R^{2}=0.82\right)$ and $89 \%\left(R^{2}=0.89\right)$ by the density of samples used. Thus, $24 \%$ of variations observed in the measurement of MOE, $18 \%$ of variations observed in the measurement of MOR an $11 \%$ of variations observed in the measurement of TS are not due to the density of samples used but rather to mere chance. 


\section{CONCLUSION}

Preliminary investigations showed that it was not possible to manufacture panels that meet requirements of panels: Grade PBU (underlayment) (Tab. II) by using only outer bark particles of white birch. An alternative method was to manufacture mixed panels (Grade PBU) with those bark particles in the surface layers reinforced by coarse wood particles in the core. The properties of manufactured mixed particleboards met the requirement of the standard of PBU grade panels. The alkali treatment of bark particles negatively affected the mechanical and physical properties of manufactured mixed particleboards, because the structure of alkali treated bark particles became weak. But these results don't mean that such an alkali treatment, done on the outer bark particles of white birch should be abandoned. Since mixed manufactured panels will be used as sub-flooring panels, the alkali treatment will help protecting them from some fungal degradation because of the high $\mathrm{pH}$ value generated and the presence of non-condensed phenol from the PF resin used to bond them (Gersonde and Deppe, 1968; Schmidt et al., 1978; Willeitner, 1956). The sub-floor is an environment where the conditions could be wet and therefore liable to deterioration of panels by fungi.

The variation of PF resin percentage in the bark particles had a highly significant effect only on the hardness, which increases with an increase in the percentage of PF resin especially in the alkali treated bark particles. The properties which are negatively affected when the fine wood particles in the face layers of wood panel are substituted by outer bark particles of white birch are MOE, MOR and IB. The advantages of such a substitution are physical properties which are significantly improved especially with untreated bark particles. The statistical analysis method used to facilitate the interpretation of physical and mechanical properties results made it possible to choose the panel with untreated bark particles bonded with 5\% PF resin as the best, especially taking into account physical properties from the measurement of thickness swelling and linear expansion, which are not only largely lower than the standard values, but also lower than the value of reference panel. The good physical properties of selected panel can easily enable its use in a moist environment like sub-flooring. Thus, the method set up for the implementation of this research project enabled to valorize up till $40 \%$ outer bark particles of white birch in each fabricated mixed panel.

Acknowledgements: Thanks to Fonds québécois de la recherche sur la nature et les technologies (FQRNT) and Université Laval for providing financial support for this research.

\section{REFERENCES}

Allison F.E., 1965. Decomposition of wood and bark sawdust in soil: Nitrogen requirements and effects on plants. USDA Agr. Res. Serv. Tech. Bull. No. 1332, 58 p.

American Society for Testing and Material 2005. D 1037-99. In: Standard test methods for evaluating properties of wood-based fiber and particle panel materials. ASTM Annual Book of Standards. Volume 04.10 West Conshohocken, Pa, pp.140-170.
Anonymous, 2005. Données sur le problème des écorces. Ministère des Ressources Naturelles du Québec (MRNQ).

ANSI, 1999. American National Standard Institute. ANSI A208.1 - 1999, Particleboard $11 \mathrm{p}$.

Blanchet P., Cloutier A., and Riedl B., 2000. Particleboard made from hammer milled black spruce residues. Wood Sci. Technol. 34: 11-19.

Boquillon N., Elbez G., and Schonfeld U., 2004. Properties of wheat straw particleboards boned with different types of resin. J. Wood Sci. 50: 230-235.

Chow P., 1976. Properties of medium-density, dry-formed fiberboard from seven hardwood residues and bark. For. Prod. J. 26(5): 48-55.

Collin J., 2003. Dispositifs expérimentaux. BVG-60678. Notes de cours, Université Laval Dost W.A., 1971. Redwood bark fiber in particleboard. For. Prod. J. 21(10): 38-43.

Fengel D. and Wegener G., 1989. Wood - Chemistry, Ultrastructure, Reactions. Walter de Gruyter, Berlin, New York, pp. 240-267.

Gersonde M. and Deppe H.J., 1968. Möglichkeiten und Verfahren Technische Voraussetzungen einer Schutzbehandlung von Holzspanplatten gegen holzzerstörende Pilze. Holzforschung 55: 876-877.

Hergert H.L., 1958. Chemical composition of cork from white fir bark. For. Prod. J. 8: 335-339.

Holloway P.J., 1972. The composition of suberin from the corks of Quercus suber L. and Betula pendula Roth. Chem. Physiol. Lipids 9: $158-170$.

Kozlowski R. and Helwig M., 1998. Lignocellulosic polymer composite. In: Prasad P.N. (Ed.), Science and Technology of Polymer and Advanced Materials, Plenum Press, New York, pp. 679-698.

Lehmann W.F. and Geimer R.L. 1976. Properties of structural particleboards from Douglas-fir forest residues. For. Prod. J. 24(10): 17-25.

Lundqvist E.K. and Back L.E., 1976. The use of bark for wood based panels. Critical evaluation. Swedish Forest Products Research Laboratory, Stockholm. Presented at ECE/FAO, Timber Division, Symposium on extending the use of wood residues, in Bucarest, Romania, September-October 1, 1976.

Maloney T.M., 1973. Bark boards from four west coast softwood species. For. Prod. J. 23(8): 30-38.

Montgomery D.C., 2005. Design and analysis of experiments. 6th ed., Arizona State University.

Nemli G. and Çolakoglu G., 2005. Effects of mimosa bark usage on some properties of particleboard. Turk J. Agric. For. 29: 227-230.

Nemli G., Gezer E.D., Y $ı$ ld $l$ S S., Temiz A., and Aydin A., 2006. Evaluation of the mechanical, physical properties and decay resistance of particleboard made from particles impregnated with Pinus brutia bark extractives. Bioresour. Technol. 97: 2059-2064.

Pedieu R., Riedl B., and Pichette A., 2008. Measurement of wood and bark particles acidity and their impact on the curing of ureaformaldehyde resin during the hot pressing of mixed panels. Holz Roh- Werkst. 66: 113-117.

Roffael E., Schneider T., Behn C., and Pedieu R., 2004. Alternativen zu OSB-Strands aus Industrieholz. Holz-Zentralblatt : unabhängiges Organ für die Forst- und Holzwirtschaft, 130 (48): 633-634.

Sampathrajan A., Vijayaraghavan N.C., and Swaminathan K.R., 1992. Mechanical and thermal properties of particleboards made from farm residues. Bioresour. Technol. 40: 249-251.

Schmidt L.E., Hall J.H., Gertjejansen O.R., Hermann J., and Hall H., 1978. Strength reductions in particleboard caused by fungi. For. Prod. J. 28(2): 26-31.

Smith J.G.H. and Kozak A., 1967. Thickness and percentage of bark of the commercial trees of British Columbia. Faculty of forestry, University of British Columbia, Vancouver, 27 p.

Swan E.P., 1968. Alkaline ethanolysis of. extractive-free western red cedar bark. Tappi 51(7): 301-304. 
Villeneuve E., 2004. Utilisation de l'écorce du peuplier faux-tremble pour la fabrication des panneaux de particules. Mémoire de maîtrise, département des sciences du bois et de la forêt, Université Laval, Québec.

Volz K.R., 1973. Production and properties of boards from spruce, pine, and beech bark. Holz Roh- Werkst. 31: 221-229.

Willeitner H., 1956. Über die Mykologische Prüfung von Holzspanplatten. Materialpruf. 7: 129-134.

Wisherd K.D. and Wilson J.B., 1979. Bark as supplement to wood furnish for particleboard. For. Prod. J. 29(2): 35-39.

Woodson G., 1975. Effects of bark, density profile, and resin content on medium density fiberboards from southern hardwoods. For. Prod. J. 26(2):39-42.

Xing C., Deng J., Zhang S.Y., Riedl B., and Cloutier A., 2006. Impact of bark content on the properties of medium density fiberboard (MDF) in four species grown in eastern Canada. For. Prod. J. 56(3): 64-69.
Youngquist J.A., 1995. Unlikely partners? The marriage of wood and non-wood materials. For. Prod. J. 45(10): 25-30.

Youngquist J.A., English B.E., Spelter H., and Chow P., 1993a. Agriculture fibers in composition panels, In: Maloney Thomas M. (ed.), Proceedings, 27th international particleboard/composite materials symposium, 1993 March 30-April 1, Pullman, WA, Washington State University, pp. 133-135.

Youngquist J.A., Myers G.E., Muehl J.M., Krzysik A.M., and Clemens C.M., 1993b. Composites from recycled wood and plastics. Final Rep., US Environmental Protection Agency, Project IAG DW12934608-2. Madison, WI: US Department of Agriculture, Forest Service, Forest Products Laboratory.

Youngquist J.A., English B.E., Scharmer R.C., Chow P., and Shook S., 1994. Literature review on use of non-wood plants fibers for building materials and panels. Gen. Tech. Rep. FPL-GTR-80. Madison, WI: US Department of Agriculture, Forest Service, Forest Products Laboratory. 